\title{
Headspace GC-MS Detection of Carbon Monoxide in Decomposed Blood and Hepatic Tissues
}

\author{
Hao $\mathrm{H}^{*}$, Zhou $\mathrm{H}^{2}$, Zen $\mathrm{L}^{1}$, Zhang $\mathrm{Z}^{1}$ and $\mathrm{Yu} \mathrm{Z}^{2}$ \\ ${ }^{1}$ Key Laboratory of Evidence Science, China University of Political Science and Law, Ministry of Education, Beijing, \\ China \\ ${ }^{2}$ Institute of Forensic Science, Ministry of Public Security, Beijing, China
}

${ }^{*}$ Corresponding author: Hao H, Key Laboratory of Evidence Science, China University of Political Science and Law, Ministry of Education, Beijing 100088, China, Fax: +86-10-68621175, Tel: +86-15010256660, E-mail: haohx@126.com

Citation: Hao H, Zhou H, Zen L, Zhang Z, Yu Z (2013) Headspace GC-MS Detection of Carbon Monoxide
in Decomposed Blood and Hepatic Tissues. J Forensic Sci Criminol 1(3): 302. doi: 10.15744/2348-9804.1.302

Received Date: November 06, 2013 Accepted Date: December 16, 2013 Published Date: December 19, 2013

\begin{abstract}
Here in a systematic, accurate and reliable method, Head-Space Gas Chromatography-Mass Spectrometry (HS-GC/MS) was developed to determine blood carboxyhemoglobin $(\mathrm{COHb} \%)$, in order to investigate deaths related to $\mathrm{CO}$ exposure especially involving blood and hepatic tissues. Using a column packed with molecular sieve, $\mathrm{COHb}$ levels were quantified down to $0.2 \%$ in small blood samples quickly and showed good reproducibility with RSD of the $\mathrm{COHb}<1 \%$. COHb\% in hepatic samples stored at different temperatures $\left(-20^{\circ} \mathrm{C}\right.$ for $1-2$ years, $0{ }^{\circ} \mathrm{C}$, and $18{ }^{\circ} \mathrm{C}$ for two months) can be determined even when the samples are decomposed. The 3 -min procedure requires only $0.25 \mathrm{~mL}$ of blood sample or $1.0 \mathrm{~g}$ of hepatic tissue each time. The technique has a clear advantage over other methods such as UV spectrophotometry.
\end{abstract}

Keywords: Carbon monoxide poisoning; $\mathrm{COHb}$; Decomposed hepatic tissues; Headspace gas chromatography/mass spectrometry (HS-GC /MS)

\section{Introduction}

Carbon monoxide (CO) exposure in humans is impossible to detect as it is colorless, tasteless, odorless, and nonirritating. When inhaled, CO is readily absorbed from the lungs into the bloodstream, where it forms a tight but slowly reversible complex with hemoglobin $(\mathrm{Hb})$ known as carboxyhemoglobin $(\mathrm{COHb})$. The presence of $\mathrm{COHb}$ in the blood decreases its oxygen-carrying capacity, reducing the availability of oxygen to body tissues, resulting in tissue hypoxia. A reduced oxygen delivery associated with elevated $\mathrm{COHb}$ level, exacerbated by impaired perfusion resulting from hypoxic cardiac dysfunction, potentially will impair cellular oxidative metabolism. In China, death due to $\mathrm{CO}$ poisoning was identified by elevated COHb levels (> 40\%) in postmortem blood.

During the past twenty years, several methods for the determination of $\mathrm{COHb}$ levels in postmortem specimens have been published. These methods include UV and FTIR spectrophotometry [1-3], CO-oximetry [2,4], and Capillary Electrophoresis (CE) [5,6]. Although gas chromatographic techniques are more suitable for forensic materials $[3,7,8]$, they are complicated, time-consuming and require larger samples when compared with CO-oximetry and GC/MS. However, $\mathrm{CO}$-oximeters cannot detect less than $10 \% \mathrm{COHb}$ content in putrid blood [4]. In China, several postmortem samples collected in suspected CO poisoning cases are decomposed and devoid of blood, as the deceased individuals were discovered days or months following death. In such cases, the quantification of $\mathrm{COHb}$ may be difficult for a toxicologist. In the present paper, the HS-GC/MS method is described for the determination of $\mathrm{COHb}$ in decomposed blood and to examine the $\mathrm{CO}$ content of the hepatic tissues extracted from cadavers in order to provide an experimental basis for the analysis of CO poisoning among deceased humans.

A study of 22 deaths resulting from unvented gas heaters revealed a mean $\mathrm{COHb}$ level of $49.5 \%$ in the victims' blood with a minimum value of about $30 \%$ and a maximum of $75 \%$ for $\mathrm{COHb}$ [9]. Another study examined the distribution of $\mathrm{COHb}$ among survivors ( mean $=28.1 \%, \mathrm{n}=159$ ) and fatalities (mean $62.3 \%, \mathrm{n}=101$ ); the $50 \%$ survival probability was associated with approximately $50 \%$ of $\mathrm{COHb}$ [10]. The liver is the largest gland in human body and plays an important role in metabolism. It has complex functions including manufacturing bile, glucose metabolism, protein metabolism, fat metabolism, biotransformation, etc. Moreover, the liver stores blood and regulates blood volume. At rest or in emotional stability, massive blood is stored in the liver. At work or when excited, the hematic quantity rises, and massive blood supplies are released 
from the liver to the body. Of all the organs, the liver and spleen have the largest blood volume, approximately 0.2-0.3 $\mathrm{mL} / \mathrm{g}$. biotransformation, etc. Moreover, the liver stores blood and regulates blood volume. At rest or in emotional stability, massive blood is stored in the liver. At work or when excited, the hematic quantity rises, and massive blood supplies are released from the liver to the body. Of all the organs, the liver and spleen have the largest blood volume, approximately 0.2 $0.3 \mathrm{~mL} / \mathrm{g}$.

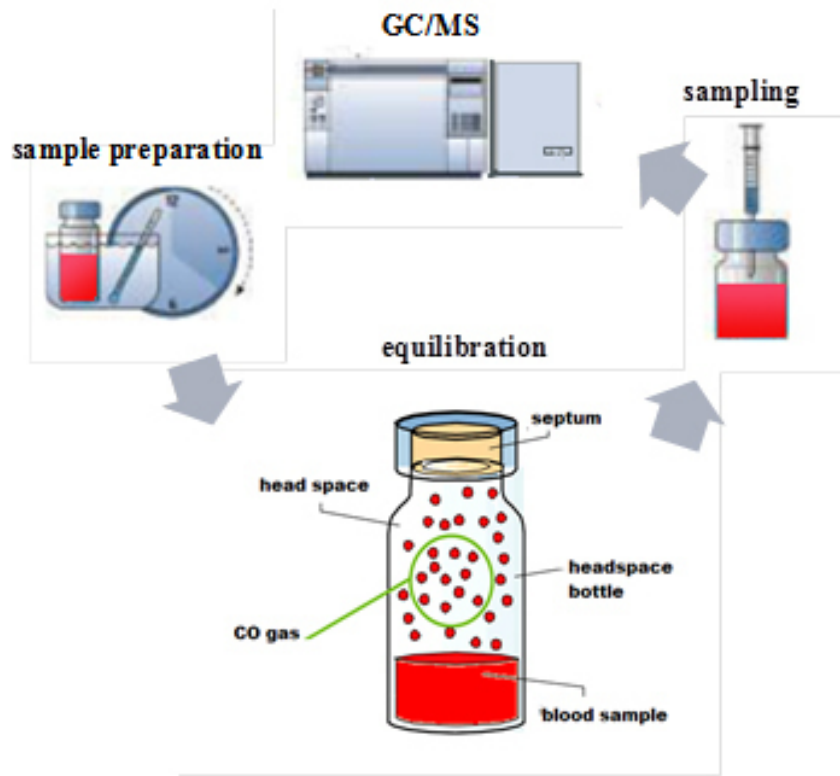

Figure 1: Experimental design and CO detection process

\section{Materials and Methods}

The protocols in this study were approved by Institutional Review Board and the Animal Care and Use Committee of China University of Political Science and Law, Ministry of Education (Beijing, China).

\section{Experimental design}

The static head-space technique is an indirect method for the analysis of volatile compounds in liquid or solid samples. Measurement of CO levels in the present study relied upon addition of lactic acid to blood samples in order to release CO. Samples were prepared as follows: blood $(0.25 \mathrm{~mL}$ per vial) was transferred into head-space vials and $0.25 \mathrm{~mL}$ of lactic acid (25\%) was added to each vial to release the CO. The vials were then heated on a heating block for $30 \mathrm{~min}$ at 50 ${ }^{\circ} \mathrm{C}$, after which $200 \mu \mathrm{L}$ of head-space gas (the vapor phase, in thermodynamic equilibrium with the sample) was extracted with a syringe for rapid analysis using gas chromatographymass spectrometry (GC/MS). The combination of GC with MS provides a powerful analytical tool for the separation and identification of individual components of an organic solution and determination of the individual quantities of each of these

When the vapor pressure of a sample is relatively low, the chromatographic peak area $\left(\mathrm{A}_{\mathrm{i}}\right)$ of a volatile component changes proportionally with its vapor pressure $\left(\mathrm{P}_{\mathrm{i}}\right)$ :
$\mathrm{A}_{\mathrm{i}}=\mathrm{S}_{\mathrm{i}} \mathrm{P}_{\mathrm{i}}$

where $S_{i}$ is the sensitivity constant of component $i$. The partial vapor pressure may be expressed as:

$\mathrm{P}_{\mathrm{i}}=\mathrm{P}_{\mathrm{i}}^{0} \mathrm{X}$

where $\mathrm{Pi} 0$ is the vapor pressure of component $\mathrm{i}$ and $\mathrm{X}_{\mathrm{i}}$ the mole fraction of the component in the sample. The chromatographic peak area $A_{i}$ can then be rewritten as:

$\mathrm{A}_{\mathrm{i}}=\mathrm{S}_{\mathrm{i}} \mathrm{P}_{\mathrm{i}}^{0} \mathrm{X}_{\mathrm{i}}=\mathrm{P} \mathrm{X}_{\mathrm{i}}$

Then the percentage saturation of blood with $\mathrm{CO}$ was calculated by the ratio of the peak areas obtained from untreated blood $\left(\mathrm{A}_{\mathrm{c}}\right)$ and $\mathrm{CO}$ saturated blood $\left(\mathrm{A}_{\mathrm{s}}\right)$ :

$\mathrm{A}_{\mathrm{c}} / \mathrm{A}_{\mathrm{s}} \times 100 \%=\mathrm{COHb} \%[8]$

where $\mathrm{A}_{\mathrm{c}}=$ Area of $\mathrm{CO}$ peak from untreated blood, and As = Area of $\mathrm{CO}$ peak from $\mathrm{CO}$-saturated blood

CO in liver $(\mu \mathrm{L})=\frac{\text { Peak Area of Hepatic Tissues }}{\text { Addictive Peak Area of Blank Liver }} \times 100$

As the blood volume in liver is constant, it may be inferred that $\mathrm{CO}$ content in the liver and blood are correlated.

When dealing with the putrid blood in CO poisoning cases, in order to saturate hemoglobin $\mathrm{CO}$ was bubbled through the same blood from the deceased. This excludes the effects of variable $\mathrm{Hb}$ concentration when dealing with putrid samples which maybe showing low or high $\mathrm{Hb}$ concentrations due to unequal setting of blood [13].

\section{Materials}

10 rabbits were purchased from Shanghai Slack Corporation (Shanghai, China). Blood was obtained from the Blood Center of the Beijing Red Cross Society. Formic acid, CO gas (99.9\%), sulfuric acid, and sodium hydroxide (to absorb gases produced from secondary reactions, such as $\mathrm{SO} 2$ and $\mathrm{SO} 3$ ) were purchased from Sinopharm Chemical Reagent Corporation (Shanghai, China).

\section{Blood sample preparation and determination}

Saturated blood preparation: Fresh blood $(150 \mathrm{~mL})$ was transferred into a conical flask (de-bubbling by n-butanol), and $\mathrm{CO}$ gas was gently bubbled through the blood for varying periods of time in order to saturate hemoglobin with $\mathrm{CO}$. The minimum time required to achieve saturation was determined to be $30 \mathrm{~min}$. Following the study of optimal N2 aeration time, a stream of nitrogen gas was passed through the blood for 5 $\mathrm{min}$ at a rate of $6-10 \mathrm{~mL} / \mathrm{min}$ to remove the free $\mathrm{CO}$ in blood. The flask was then covered with a tight-fitting lid and shaken slowly for $30 \mathrm{~min}$, after which the sample was transferred and preserved at $4^{\circ} \mathrm{C}$ in an airtight container. Blood samples prepared as described above were considered to have a $\mathrm{COHb}$ saturation of $100 \%[7,8]$.

Blank blood preparation: Air was bubbled through $100 \mathrm{~mL}$ of fresh blood for $30 \mathrm{~min}$ followed by a stream of nitrogen gas for $5 \mathrm{~min}$. The blank blood was then preserved at $4^{\circ} \mathrm{C}$ in an airtight container. 
Preparation of a concentration series of $\mathrm{COHb}$ blood: Appropriate volumes of $\mathrm{COHb}$-saturated blood and blank blood were mixed to prepare of a series blood samples containing various $\mathrm{COHb}$ concentrations: $0 \%$ (blank blood), $10 \%, 20 \%, 30 \%, 40 \%, 50 \%, 60 \%, 70 \%, 80 \%, 90 \%$ and $100 \%$. These samples were preserved in sealed syringes and stored in airtight containers at $4^{\circ} \mathrm{C}, 17^{\circ} \mathrm{C}$, and $-20^{\circ} \mathrm{C}$.

Headspace sample preparation: A $0.25 \mathrm{~mL}$ aliquot of blood was placed into a $10-\mathrm{mL}$ head-space vial. To this was added 0.5 $\mathrm{mL}$ of distilled water and $0.25 \mathrm{~mL}$ of $25 \%$ lactic acid and the vial was covered immediately with an aluminum cap containing a rubber septum. The vial was then heated on a heating block for $30 \mathrm{~min}$ at $50^{\circ} \mathrm{C}$ and $200 \mu \mathrm{L}$ of gas was extracted for GC/MS analysis.

Determination the $\mathrm{COHb}$ linear range of blood: Head-space samples were prepared as above using $0.25 \mathrm{~mL}$ of blood from each of the following standard concentrations of $\mathrm{COHb}$ in blood: $0 \%$ (blank blood), 10\%, 20\%, 30\%, 40\%, 50\%, 60\%, 70\%, $80 \%, 90 \%$ and $100 \%$. GC/MS analysis of each of these samples enabled the construction of a standard curve for $\mathrm{COHb} \%$.

\section{Determination of $\mathrm{CO}$ in hepatic tissues}

Experimental animal hepatic tissue: Healthy male rabbits (10) with similar weight were taken, No.1 and No10 rabbits were sacrificed by intravenous injection of air into ear margin; another 8 died of $\mathrm{CO}$ poisoning. The experiment was so designed that male rabbits inhaled $\mathrm{CO}$ ( $\mathrm{CO}>1 \%$, lasting for $30 \mathrm{~min}$ ) in an exposure apparatus, i.e. a homemade glass box with CO gas inlet and outlet. Immediately after death, the blood and hepatic tissue samples were collected and analyzed for $\mathrm{CO}$ and $\mathrm{COHb}$ with HS-GC/MS. Finally, hepatic tissue was extracted (Figure 2).

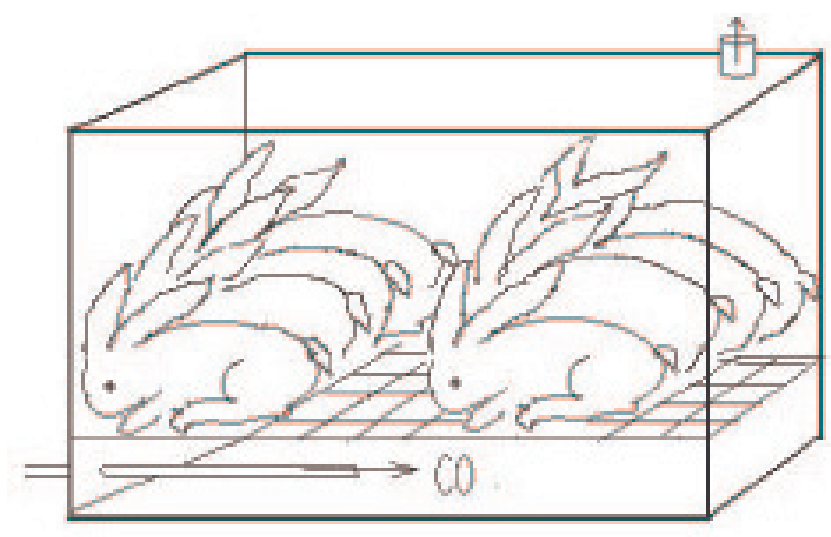

Figure 2: Testing equipment for CO poisoning of animals

It was observed that exposure to $\mathrm{CO}$ at 4600 to $5000 \mathrm{ppm}$ and $\mathrm{COHb}$ levels greater than $60 \%$ for $30 \mathrm{~min}$ causes death of rabbits within minutes of exposure, the rabbits' eyes began twitching and their lips turned red. After 10 minutes later, the rabbits began to scream and $30 \mathrm{~min}$ later, the rabbits died one by one, with their lips and mouth open. After the dissection, 10-15 mL of the cherry-red cardiac blood was transferred into an airtight cuvette. Remaining organs were transferred into bags and sealed. Livers, which were used in the present study, and other organs stored as samples for use in later experiments.
Determination of CO in hepatic tissues: About $1.0 \mathrm{~g}$ of hepatic tissues was isolated, and subjected to similar analysis as described above. The determination of $\mathrm{CO}$ content in putrid liver tissues was as follows: the hepatic tissues were prepared as above and stored in sealed plastic bags at room temperature $\left(15 \sim 17^{\circ} \mathrm{C}\right)$. On the 8 th day blood on the liver surface darkened and the 35th day when the liver turned into mud with a terrible smell. Sample preparation and CO analysis was similar as described in the previous section. Preparation of saturated hepatic tissue entailed transferring $1.0 \mathrm{~g}$ blank liver into the hepatic tissue as described previously. About $100 \mu \mathrm{L}$ sterling CO.

Stability of bloods COHb\%: Three $0.25 \mathrm{~mL}$ portions of four different $\mathrm{COHb}$ blood concentrations $(\mathrm{n}=3$ for each temperature) were stored under airtight conditions at $4^{\circ} \mathrm{C}$, $17^{\circ} \mathrm{C}$ and $-20^{\circ} \mathrm{C}$ (Table 1 ).

\section{GC/MS analysis}

A Shimadzu GC/MS System Model QP 5000 was used as follows: (1) GC parameters: fused silica capillary column with Hp-plot, $30 \mathrm{~m} \times 0.25 \mathrm{~mm} \times 12 \mu \mathrm{m} 5 \mathrm{~A}$ Molecular sieve (Shimadzu); column temperature heated from $50-250{ }^{\circ} \mathrm{C}$; injection temperature, $250^{\circ} \mathrm{C}$; carrier gas, He flow, $1.5 \mathrm{~L} / \mathrm{min}$, splitting ratio 10: 1 ; head-space injection. (2) MS parameters: mass range 10 60; scanning interval $0.5 \mathrm{~s}$; acquisition time, $0.5 \sim 3 \mathrm{~min}$; source temperature $200^{\circ} \mathrm{C}$. multiplier voltage, 1.35 $\mathrm{kV}$; electronic energy, $70 \mathrm{eV}$.

Samples were prepared as follows: Blood $(0.25 \mathrm{~mL}$ each $)$ and hepatic tissues $(1.0 \mathrm{~g}$ each) were transferred into headspace vials separately which released $\mathrm{CO}$ after addition of $25 \%$ lactic acid. The vials were then heated for $30 \mathrm{~min}$ at $50{ }^{\circ} \mathrm{C}$, from which $200 \mu \mathrm{L}$ headspace gas was extracted for accurate and rapid GC/MS analysis. The samples were then stored in test tubes with plugs at different temperatures $\left(-20^{\circ} \mathrm{C}, 0^{\circ} \mathrm{C}, 18^{\circ} \mathrm{C}\right)$ and $\mathrm{COHb}$ was determined after 7 days, 14 days, 30 days and 40 days. In each experiment, three samples were prepared in parallel $(n=3)$ and each sample was analyzed 5 times. Extra care was taken to ensure that each $200 \mu \mathrm{L}$ extraction of headspace gas was carried out accurately and used rapidly for GC/ MS analysis.

\section{Comparison with UV method}

To perform UV-VIS analysis, one drop of blood samples was added to a test tube containing $5.0 \mathrm{~mL}$ sodium hyposulfate solution and gently shaken (Table 2).

\section{Results and Discussion}

In this paper, a protocol was established for the determination of CO content in liver tissues. The stability of CO in blood was investigated and the experimental basis for these cases of $\mathrm{CO}$ poisoning was determined.

\section{CO stability in blood}

In 2000, Kunsman [11] reported that COHb levels in blood were stable for two years. In reality, blood in CO poisoning 


\begin{tabular}{|c|c|c|c|c|c|c|c|c|c|}
\hline \multirow[t]{3}{*}{ Temperature } & \multirow[t]{3}{*}{ Time } & \multicolumn{8}{|c|}{ Measured values of COHb in blood (mean) } \\
\hline & & \multicolumn{2}{|c|}{$10 \%$} & \multicolumn{2}{|c|}{$30 \%$} & \multicolumn{2}{|c|}{$50 \%$} & \multicolumn{2}{|c|}{$70 \%$} \\
\hline & & HS-GC/MS & UV & HS-GC/MS & UV & HS-GC/MS & UV & HS-GC/MS & UV \\
\hline \multirow[t]{4}{*}{$4^{\circ} \mathrm{C}$} & 1 & 10.0 & 10.0 & 30.1 & 30.3 & 49.7 & 50.7 & 70.0 & 70.0 \\
\hline & 4 & 10.5 & 9.6 & 29.6 & 28.1 & 49.8 & 46.6 & 70.1 & 62.8 \\
\hline & 14 & 9.6 & -- & 28.1 & 28.8 & 48.6 & 48.1 & 68.8 & 33.6 \\
\hline & 45 & 9.6 & -- & 28.9 & -- & 47.7 & --- & 68.9 & 32.7 \\
\hline \multirow[t]{4}{*}{$17^{\circ} \mathrm{C}$} & 1 & 10.0 & 8.4 & 31.2 & 25.8 & 50.7 & 49.9 & 69.4 & 66.3 \\
\hline & 4 & 10.7 & -- & 29.9 & --- & 49.5 & 35.5 & 68.4 & 28.6 \\
\hline & 14 & 9.4 & -- & 29.8 & 10.8 & 48.9 & 22.3 & 69.7 & -- \\
\hline & 45 & 9.8 & -- & 28.5 & -- & 49.1 & -- & 69.5 & -- \\
\hline \multirow[t]{4}{*}{$-20^{\circ} \mathrm{C}$} & 1 & 10.1 & 10.0 & 31.1 & 30.0 & 52.6 & 50.7 & 71.4 & 72.9 \\
\hline & 4 & 10.4 & 10.0 & 30.9 & 30.3 & 51.1 & 50.7 & 69.2 & 60.0 \\
\hline & 14 & 10.0 & 9.6 & 29.7 & 28.1 & 49.7 & 51.7 & 68.3 & 62.8 \\
\hline & 45 & 9.1 & --- & 32.5 & --- & 54.6 & 56.6 & 72.9 & 33.6 \\
\hline
\end{tabular}

*-- not detectable

Table 1: Stability of COHb under different storage conditions

\begin{tabular}{|c|c|c|c|c|}
\hline \multirow{2}{*}{ Rabbits } & \multicolumn{2}{|c|}{ COHb\% (HS-GC/MS) } & COHb\% (UV method) \\
\hline & $0 \mathrm{~d}$ & $8 \mathrm{~d}$ & $35 \mathrm{~d}$ & $35 \mathrm{~d}$ \\
\hline 1 (blank) & 0.2 & 0.2 & 2.3 & -- \\
\hline 2 & 62.1 & 61.2 & 57.0 & -- \\
\hline 3 & 68.8 & 64.0 & 64.3 & 28 \\
\hline 4 & 63.4 & 63.4 & 64.6 & -- \\
\hline 5 & 68.3 & 62.4 & 60.0 & -- \\
\hline 6 & 73.2 & 70.7 & 69.1 & 29 \\
\hline 7 & 67.5 & 62.0 & 65.7 & -- \\
\hline 8 & 64.5 & 64.5 & 64.5 & -- \\
\hline 9 & 64.6 & 65.4 & 63.6 & -- \\
\hline 10 (blank) & 0.6 & 0.6 & 0.5 & -- \\
\hline
\end{tabular}

*-- not detectable, $\mathrm{d}=$ day

Table 2: Comparison of the saturation levels at room temperature

cases is left outside for extended periods of time before it is sent to the laboratory for analysis. Our research emphasizes on the stability of $\mathrm{COHb}$ under ambient conditions or low temperature (for instance, $0 \sim 4{ }^{\circ} \mathrm{C}$ or $-20{ }^{\circ} \mathrm{C}$ ). Standard $\mathrm{CO}$ blood was prepared at different concentrations $(10 \%, 30 \%, 50 \%$, and $70 \%)$, stored at room temperature $\left(17 \sim 19{ }^{\circ} \mathrm{C}\right)$, refrigerated at $0 \sim 4{ }^{\circ} \mathrm{C}$, or in cold storage at $-20^{\circ} \mathrm{C}$. Table 1 shows the experimental results.

Based on the data shown in Table 1, it is concluded that both time and temperature affect the determination of $\mathrm{COHb}$, with $4{ }^{\circ} \mathrm{C}$ being the most suitable temperature for storage. Under prolonged conditions of freezing, $\mathrm{COHb}$ in the blood sample appears to rise, possibly due to unstable or low temperatures.

At freezing temperatures below $-30{ }^{\circ} \mathrm{C}$, the level of blood methemoglobin (MetHb) increases. When it does not combine with $\mathrm{CO}$ the high levels of MetHb diminish the ability of $\mathrm{CO}$ complexation resulting in elevated levels of $\mathrm{COHb}$ [12].

The HS-GC/MS method offers a clear advantage over the UV method as seen from the data in Table 1. When the specimens were stored at room temperature, the $\mathrm{COHb}$ levels were reduced by about half: the original $70 \% \mathrm{COHb}$ levels fall to $45.1 \%$, which implies that it was not a case of CO-poisoning

death, contrary to the facts.

\section{Determination of CO content in liver tissues}

The No.1 and No.10 rabbits died of intravenous injection of air into ear margin. Results from animal experiments of COpoisoning death are shown in chart 2 revealing that the content of CO is sharply reduced with increased storage time of liver tissue. The reduced ratio needs further study.

The hepatic tissues were isolated on the day of the rabbit death. The samples from rabbit No.1-5 were placed at room temperature $\left(15-17^{\circ} \mathrm{C}\right)$; No.6, 7, 10 under freezing temperature; and those from No.8, 9 cryopreserved. All blood samples were in good condition at the baseline. They were cherry-red, and delaminated after stratification. After storage at room temperature for 2 days, the blood darkened and the sample hemolyzed. The blood turned into dark red after 45 days of preservation. When the blood was stored at $4{ }^{\circ} \mathrm{C}$, no obvious change occurred in the first 8 days. After one month the color turned dark after which the sample became moderately hemolyzed 35 days later. When the blood was preserved at $-20{ }^{\circ} \mathrm{C}$, no obvious change was seen within one month, however, it turned dark after one month and the sample was hemolyzed after 35 days. When the hepatic tissue was stored at normal temperature, the blood agglutinated to the surface, the tissue started to decompose, and the color became garnet. The liver became highly decomposed after 35 days turning into a greyish-green and malodorous mush (Figure 3, Table 2).

\section{Comparison of HS/GC/MS and UV techniques for measurement of $\mathrm{CO}$ levels}

The bodies of two people were found 4 days after death by $\mathrm{CO}$ poisoning. The blood samples were stored at room temperature for 15 days, and then transferred to our lab. The blood turned black-red and no results were available when they were analyzed by the UV method. However, using the HS/GC/MS method we developed, the $\mathrm{COHb}$ was detected as showed in Table 3 and Figure 4. 


\begin{tabular}{|c|c|c|c|c|c|c|c|}
\hline & Area of blood & $\begin{array}{l}\text { Area of CO- } \\
\text { saturated blood }\end{array}$ & $\begin{array}{c}\text { Area of hepatic } \\
\text { issues }\end{array}$ & $\begin{array}{c}\text { Area of CO- } \\
\text { saturated hepatic } \\
\text { issues }\end{array}$ & $\begin{array}{c}\text { Volume of CO } \\
\text { in hepatic issues } \\
(\mu \mathrm{L})\end{array}$ & $\mathrm{COHb} \%$ & $\mathrm{COHb} \%$ \\
\hline A & 249518 & 366275 & 219258 & 478256 & 49.8 & $65.1 \%$ & UV method \\
\hline B & 337065 & 513052 & 428105 & 956339 & 58.0 & $68.7 \%$ & -- \\
\hline
\end{tabular}

*-- not detectable

Table 3: Specimen analysis

\begin{tabular}{|c|c|c|c|c|c|}
\hline Area of blood & $\begin{array}{c}\text { Area of CO- satu- } \\
\text { rated blood }\end{array}$ & $\begin{array}{c}\text { Area of hepatic } \\
\text { issues }\end{array}$ & $\begin{array}{c}\text { Area of CO-saturat- } \\
\text { ed hepatic issues }\end{array}$ & $\begin{array}{c}\text { COHb\% } \\
\text { hepatic issues }(\mu \mathrm{L})\end{array}$ & $\begin{array}{c}\text { COHb\% }(\mathrm{UV} \\
\text { method) }\end{array}$ \\
\hline 310603 & 586305 & 996706 & 4010199 & $52.9 \%$ & 33.1 \\
\hline
\end{tabular}

*-- not detectable

Table 4: Results of CO poisoning specimens after 2 years of cryopreservation.

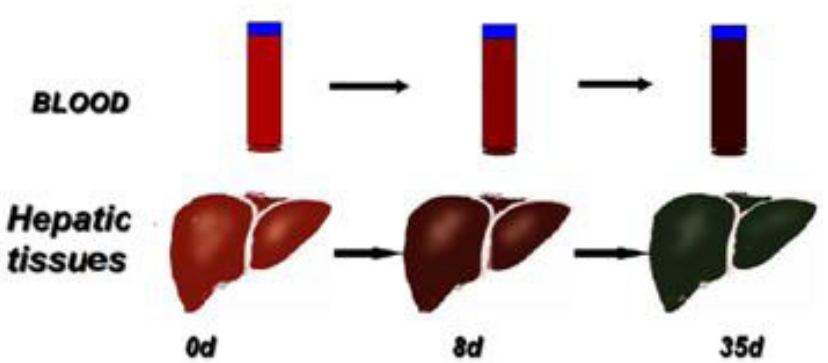

Figure 3: Change in samples at room temperature

\section{Comparison of HS/GC/MS and UV techniques for measurement of CO levels}

The bodies of two people were found 4 days after death by $\mathrm{CO}$ poisoning. The blood samples were stored at room temperature for 15 days, and then transferred to our lab. The blood turned black-red and no results were available when they were analyzed by the UV method. However, using the HS/GC/MS method we developed, the $\mathrm{COHb}$ was detected as showed in Table 3 and Figure 4.

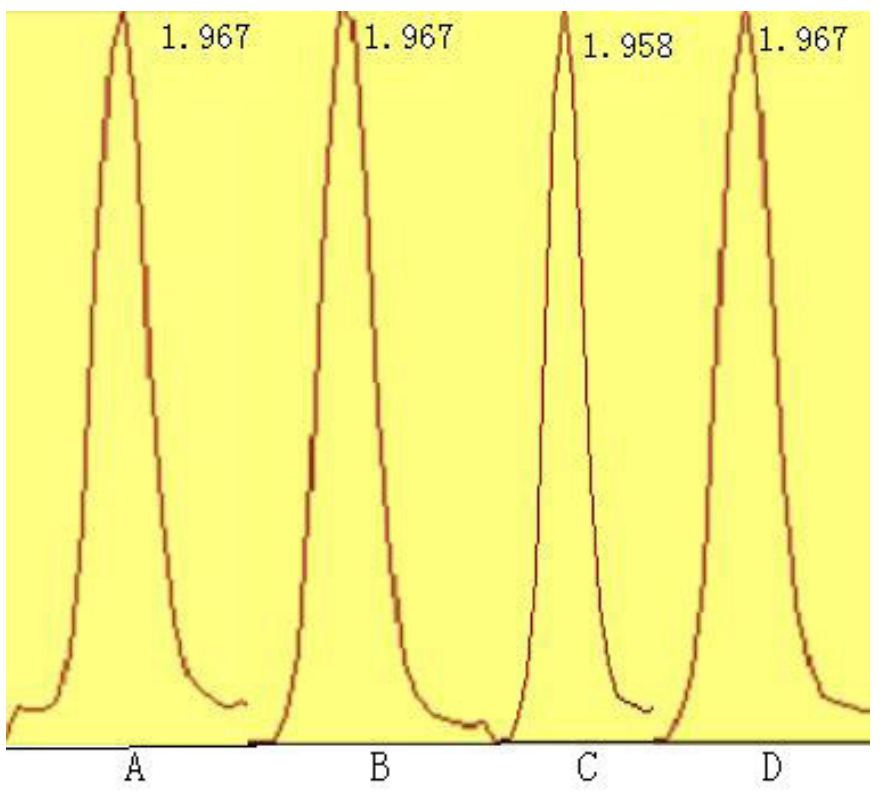

Figure 4: Mass chromatograms of the blood and hepatic tissue specimens

The blood samples from $\mathrm{CO}$ poisoning death $(\mathrm{COHb} \%$ of $54 \%)$ were cryopreserved for two years and analyzed again by HS-GC/MS method as showed in Table 4.
In contrast, use of UV spectrometry provided values of $\mathrm{COHb} \%$ that were well below $30 \%$, and in the first case not detectable, which would not have supported CO poisoning as the cause of death in all individuals. The UV method is often used to detect $\mathrm{CO}$ concentrations in fresh blood samples, but may not be suitable for decomposed blood, where it may give values lower than the true levels. Thus, the HS/GC/MS technique may have significant advantages over the UV method, particularly when blood samples are not fresh.

\section{Conclusion}

HS/GC/MS is associated with high sensitivity regardless of the sample condition - fresh or highly decomposed. Using a packed molecular sieve column, CO levels were able to be quantitating down to $0.01 \%$ and $\mathrm{COHb}$ levels down to $0.2 \%$ in small blood $(0.25 \mathrm{~mL})$ and liver $(1.0 \mathrm{~g})$ samples. Our method showed that we can disregard the strong effect of storage temperature on the $\mathrm{COHb} \%$ determination. The equipment is easily available since most labs already have gas chromatography and mass spectrometry instrumentation. In fact, manual injection may substitute for the absence of a headspace automatic sampler. The method has a much higher sensitivity than the commonly used techniques such as UV method.

\section{Acknowledgements}

We are grateful to The Program for Young Innovative Research Team in China University of Political Science and Law, Program for Changjiang Scholars and Innovative Research Team in University (IRT0956), China Scholarship Council Fund, and Academician Foundation of the Ministry of Public Security (No.2011-23210044, 2011-23211119) for their financial supports.

\section{References}

1. Van Dam J, Daenens P (1994) Microanalysis of carbon monoxide in blood by head-space capillary gas chromatography. J Forensic Sci 39: 473-8.

2. Oritani S, Zhu BL, Ishida K, Shimotouge K, Quan L, et al. (2000) Automated determination of carboxyhemoglobin contents in autopsy materials using head-space gas chromatography/mass spectrometry. Forensic Sci Int 113: 375-9. 
3. Lewis RJ, Johnson RD, Canfield DV (2004) An accurate method for the determination of carboxyhemoglobin in postmortem blood using GC-TCD. J Anal Toxicol 28: 59-62.

4. Brehmer C, Iten PX (2003) Rapid determination of carboxyhemoglobin in blood by Oximeter. Forensic Sci Int 133: 179-81.

5. Fechner GG, Gee DJ (1989) Study on the effects of heat on blood and on the post-mortem estimation of carboxyhaemoglobin and methaemoglobin. Forensic Sci Int 40: 63-7.

6. Chaturvedi AK, Smith DR, Canfield DV (2001) Blood carbon monoxide and hydrogen cyanide concentrations in the fatalities of fire and non-fire associated civil aviation accidents, 1991-1998. Forensic Sci Int121: 183-8.

7. Collison HA, Rodkey FL, O’Neal JD (1968) Determination of carbon monoxide in blood by gas chromatography. Clin Chem 14: 162-71.

8. Wallace KL, Curry SC (2002) Postcollection Rise in Methemoglobin Level in Frozen Blood Specimens. J Toxicol Clin Toxicol 40: 91-4.
9. Tyrrell EA, Kale DA (1979) Unvented gas space heater related deaths. U.S. Consumer product safety commission memorandum 1: 1-7.

10. Pach J, Cholewa L, Marek Z, Bogusz M, Groszek B (1979) Analysis of predictive factors in acute carbon monoxide poisoning. Vet Hum Toxicol 21 Suppl: 158-9.

11. Kunsman GW, Presses CL, Rodriguez P (2000) Carbon monoxide stability in stored postmortem blood samples. J Anal Toxicol 24: 572-8.

12. Wright RO, Lewander WJ, Woolf AD (1999) Methemoglobinemia: etiology, pharmacology, and clinical management. Ann Emerg Med 34: 646-56.

13. Yu Z (1992) Determination of carbon monoxide in biological tissues by Headspace-Gas Chromatography. Journal of Chinese Forensic Medicine 7: 12.

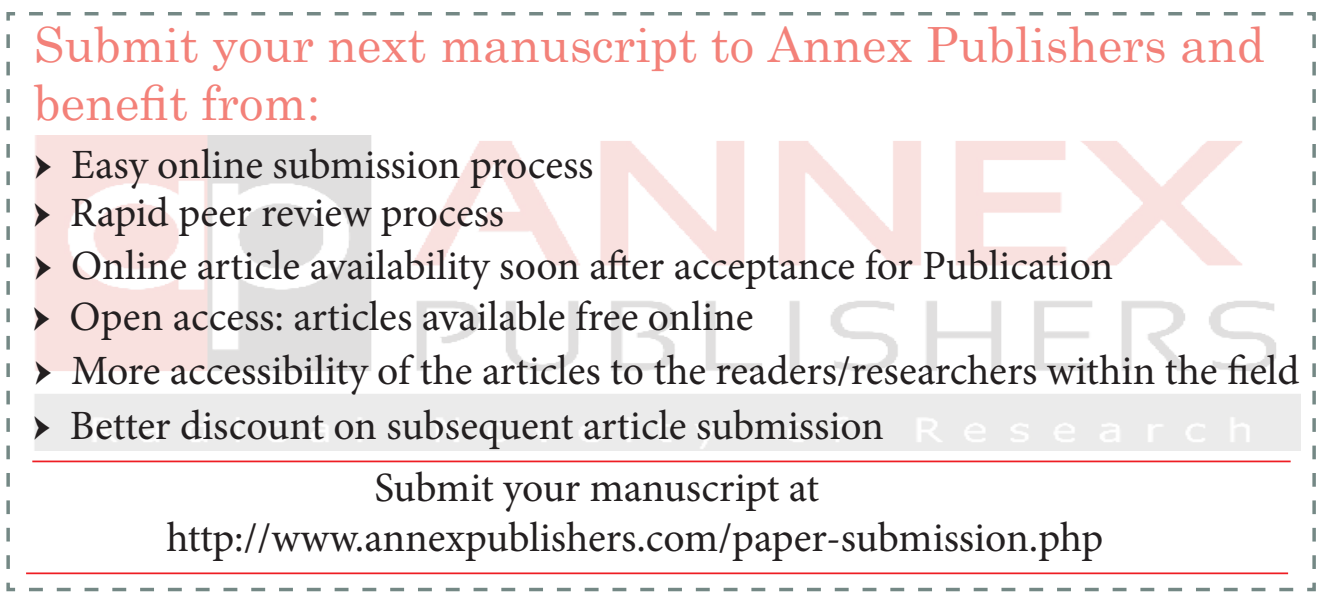

